УДК 811.111'06'42:343.102

https://doi.org/10.31548/philolog2021.01.117

\title{
NARRATIVE IN THE DISCOURSE OF INTERROGATION
}

\author{
L. V. PAVLICHENKO, PHD in Linguistics, assistant, \\ Taras Shevchenko National University of Kyiv \\ E-mail: la.pavlichenko@gmail.com \\ https://orcid.org/0000-0003-3801-2587
}

\begin{abstract}
The analysis of the English-language narrative of interrogation at the stage of pre-trial investigation from the standpoint of communicative pragmatics helps to optimize international professional communication, specifies and clarifies the speech situation "investigator - interrogated person", and corresponds to modern scientific research in the field of cognitive-discursive paradigm of linguistics. The purpose of this study is to analyze the communicative and pragmatic characteristics of the narrative of the interrogated person in the modern English interrogation discourse at the stage of pre-trial investigation. The formality, stenciling and ritualization of the interrogation discourse is manifested by the structurally invariant parts in the dialogical text of the interrogation: "introduction", "directed narrative" and "verification". This structure is typical for both primary and secondary stages of interrogation. The institutional form of interrogation is a combination of a narrative with dialogical communication of a police officer and an interrogated person ("narrative as an interactional event"), in the process of which an investigator specifies, reformulates or expands the interrogee's narrative with leading questions and comments. The specificity of the chronotope is a constitutive characteristic feature of the interrogation discourse: the prototype place of communication is a police investigator's office; in terms of time, the discourse of interrogation is marked by anachronism as the discrepancy between the time of discourse and the time of narration by an interrogated person, which is manifested in the use of different grammatical verb forms and adverbs for the time of discourse and for time of "stories" told by an interrogated person. The structure of the temporal organization of interrogation discourse is characterized by frequent mentioning of a key event by both investigators and interrogees in order to identify or emphasize details and circumstances of the case.
\end{abstract}

Keywords: investigator, interrogated person, interrogation discourse, pre-trial investigation, directed narrative, dialogical communication.

The topic of the study is relevant due to its correspondence to modern scientific research in the field of cognitive-discursive paradigm of linguistics concerning pragmatic factors of optimization of oral institutional interaction, study of speech influence, prevention and overcoming of interaction failures and conflict communication.

The purpose of the research is to analyse the communicative-pragmatic characteristics of a narrative of an interrogated person in interrogation discourse.

The materials of the study were transcripts of interrogations at the stage of pre-trial investigation, obtained by the method of continuous sampling.

Due to the "narrative turn" in interdisciplinary research, methodological postulates and principles of narrative analysis are increasingly involved for the study of judicial and pre-trial discourse. Examination of the records reveals that, first of all, the narrative perspective is used in the analysis of "stories" and "competing stories" (Heffer [9, 10], Harris [8], Cotterill [5]) of witnesses during the trial. Among the most original and influential works in this field are works (Bennett and Feldman [2]; Maley and Fahey [12]) that are devoted to the study of evidence as narratives, in which a definition of the types of such narratives is proposed: spontaneous, prompted and evoked.
The review of the sources allows to state that the narrative of witnesses / interrogees is partially constructed by the questions posed to them (Harris [7], Luchjenbroers [12, p. 501]). According to the sources, the "dual authorship" of the narrative in the courtroom and the various narrative versions of the same crime were explored in Cotterill's writings [4]. Apart from the above mentioned reviews, not a single scholarly work has appeared devoted to the study of the interrogated person's narratives in the pre-trail investigation.

Research results. It is well to begin with a little clarification on the composite structure of the interrogation. According to the structure, the following stages of interrogation at the stage of pretrial investigation can be distinguished: initial, main and final. At the initial stage, the investigator prepares in advance for the interrogation, collects all possible information about the interrogated person and the circumstances of the crime. He draws up a rough plan of the interrogation, considers the problems that may arise, compiles a list of questions, outlines the tactics of the dialogue.

In addition, the duty of the investigator at the preliminary stage of interrogation is to explain to the interrogated person his/her rights and responsibilities, warning, when it comes to a witness or a victim, of criminal liability for evasion or refusal to testify or give false testimony, the right 
do not testify against himself/herself. The following explanations are given as clichéd formulas, etiquette speech stereotypes:

"Pepe: When any person is arrested they have certain rights, Ok, the right to say nothing, that is, you do not have to say anything unless you wish to do so, but what you say may be used as evidence. Now I want you to understand that, that any answer that you give to me is at your own free will" [14].

It should also be emphasized that main purpose of any interrogation is to obtain new and truthful information that is important to the case under investigation. This goal will determine the main stage of the interrogation, when the interrogated person is asked to freely present all the information and facts that he has, in the sequence that he deems necessary, and with his own assessments (stage of free storytelling). Thus, at the main stage, the interrogation takes the form of a "directed" narrative, as the investigator adjusts the process of giving evidence through questions and comments, helping the interviewee to recall the sequence of events, details and facts that may be important to the case, in a free story, as well as to reproduce missing or hidden facts or circumstances that are significant.

At the same time, certain elements of the narrative may be part of the initial stage of the interrogation if the interrogated is required to present the case consistently.

At last, the final stage of the interrogation, the data obtained during the interrogation are recorded. The investigator draws conclusions based on the information obtained, the data are reviewed, compared with the testimony of other witnesses, as well as with the data obtained during previous interrogations.

Thus, the structural components of the interrogation can be divided into "introduction", "directed narrative" and "verification". This structure is typical for both primary and secondary interrogation with the difference that for the second stage the narrative of events has less functional load than part of the "verification" such as confirmation, verification, addition, clarification of data obtained during conducting preliminary interrogations.

So, the discourse of interrogation by its form is a "directed" narrative that combines the "story" of the interrogated in the form of a free storytelling with dialogic communication, as the model of events reproduced by the interrogated person must be clarified, supplemented, verified by leading questions of the investigator. At the stage of "questions" there is a correct formulation and the correct order, especially taking into considersation that the models of the crime situation from the investigator and the interrogated person can differ significantly.

If we use the terminology of conversational analysts dealing with alternative methods of narrative research (C. Antaki [1]; B. Benwell [3]; N.R. Norrick [13]), the "story" of the respondent is a kind of "narrative in interaction". The study of such narratives focuses on the analysis of how a story told by one of the interactants is "embedded" in the interaction under the condition of "interfering" in the story of the second communicator, for example, through rewording of the story or other actions in the process of clarifying the meaning of the narrative.

In the discourse of interrogation, such stories may follow a special invitation from the investigator, i.e. initiated by one of his questions, or be suggested by the interrogated persons themselves, preceded by questions from the investigator:

"MacLeod: Right. Let's forget Friday then. Let's talk about Saturday, we've been over this before. Let's talk about the telephone call.

Smith: Right.

MacLeod: Ok. Right. Talk me through it again.

Smith: The telephone call. It was, I mean, we have it on tape, so I don't suppose it makes much difference discussing the details, because I don't, you know, at the time I didn't get all the details clearly. I heard the telephone call, the telephone rang, my wife picked it up and answered. We know it was a guy called George, who wanted to speak to a Michael Smith. I think he said Michael Smith, or was it Mike Smith, I don't know. I was passed the phone by my wife, I heard this foreign sounding man. I gave a few yes, ok, sort of answers. What do you want to know now?"[14].

Thus, the role of the investigator as an institutional subject presupposes their "complicity" in discovering the meaning and constructing the narrative of the interrogated person. In particular, the investigator adjusts the interviewee's narrative by focusing on the details of the story in order to recover forgotten or unintentionally omitted facts or to disclose information that the interviewee may conceal or distort: ("Let us talk about the walking then", "Let us go back to today then", "I want you to think just for a minute on this telephone conversation"[14]).

Another possibility for the investigator to interfere in the narrator's narrative is a warning about criminal liability for providing of false testimony (covert incentive for a witness to return to their narrative with the disclosure of details):

"Mr Smith, I must warn you, still, that you are under caution, and you are not obliged to say anything. You understand the caution?"[14].

If the an interrogated person refuses to testify, the investigator may initiate the continuation of his story with the help of manipulative techniques and tactics:

"I am telling you, I have evidence", "Do you feel that there is something in your behavior this 
morning that is unreasonable for you to answer?"[14].

Finally, the story told by the interrogated person can be used by the investigator to interpret other facts and details of the case:

"Smith: I don't feel any pride in the fact that, what happened then, happened the way it did. I, if it could have happened any differently, I would have changed it. But l'd be stupid to say that I didn't go into it feeling, well, that there wasn't anything to find out, that these people would just allow me to continue.

MacLeod: So, you thought it would be quite acceptable, for somebody of communist persuasion to hold the position ..." [14].

In the process of reformulating or expanding the narrator's narrative, the investigator not only loses a number of his own communicative roles, but also offers inverse (paired) roles to the interrogated person. Such roles can be supported or denied. Thus, one of the predicted signs of role resistance on the part of the witness is a delay in response (in the form of verbalized or unfilled gestational pauses):

"um, you know to get down on the boat and ah again we were I think we were last onto the boat" [15].

As for the temporal characteristics of interrogation discourse (Genette [6]), it is characterized by a variety of temporal instances, which is manifested in the use of different grammatical verb forms for the discourse time and "story" time, which the interrogee sets out in the chronological order that he considers most relevant to his "narrative":

"Beels: Where had she been, incidentally, where had you wife been incidentally that morning?

Smith: She had an appointment. What was it? I don't know if - I'm getting a bit confused now, as to what days what things happened either Tuesday or Wednesday she had to go to the dentist. I thought it was Tuesday. She went on Wednesday for some reason - then either that was the dentist, or it was some other reason, but she said she would, she was going, she would know more than I would where she was going. But I remember her telling me, but I don't know where, she went to the hairdresser on one day. I don't think" [14].

Thus, in the above mentioned fragment of the dialogue, the time of discourse is the present tense (both simple and perfect), in which the

\section{References}

1. Antaki, C. (1998) Identities in Talk. London: Sage Publications, $224 \mathrm{p}$.

2. Bennett, W. Lance; Feldman, Martha S. (1981) Reconstructing Reality in the Courtroom. Authors, Edition, illustrated. Publisher, Tavistock, $203 \mathrm{p}$.

3. Benwell B., Stokoe E. (2006) Discourse investigator addresses his questions to the interrogated person (suspect).

On the other hand, the "history" of the interrogated person involves such different temporal instances as the use not only of the past and past continuous tenses as it is quite logical for the narration of events important for the investigation, but also its combination with the present, including simple and continuous forms.

In addition to anachronism as a discrepancy between the time of discourse and the time of narration, the structure of the temporal organization of interrogation discourse is characterized by the frequency of mentioning a key event by both investigators and interrogees in order to identify or emphasize details and circumstances of the case.

Conclusions. Thus after carrying out the description and analysis, it became possible to arrive at the following conclusions. The formality, stenciling and ritualization of the interrogation discourse at the stage of pre-trial interrogation is characterized by the presence of structurally invariant parts in the dialogical text of the interrogation: "introduction", "directed narrative" and "verification".

The specificity of the chronotope is a constitutive characteristic of the interrogation discourse: the prototype place of communication is the investigator's office; in terms of time, the discourse of interrogation is marked by anachronism as the discrepancy between the time of discourse and the time of narration, which is manifested in the use of different grammatical verb forms for the time of discourse and time of "stories".

The institutional form of interrogation is a combination of a narrative with dialogic communication ("narrative as an interactional event"), in the process of which the investigator specifies, reformulates or expands the narrator's (interrogated person's) narrative with leading questions and comments. The "complicity" of the investigator in expanding the meaning of the narrator's narrative is manifested in focusing on the details of the story in order to restore forgotten or unintentionally missed facts; application of manipulative techniques and tactics, warning of criminal liability (stimulation of a witness to return to his narrative with the disclosure of details); using the formulated history as a basis for interpreting other facts and details of the case.

and Identity. Edinburgh: Edinburgh University Press, $314 \mathrm{p}$.

4. Cotterill, J. (2002) (Ed.) Language in the Legal Process. Hampshire: Palgrave Macmillan, P. 147-161.

5. Cotterill, J. (2003). Language and Power in Court: A Linguistic Analysis of the O.J. Simpson Trial. Basingstoke: Palgrave Macmillan. 245 p. 
6. Genette, G., Narrative Discourse: An Essay in Method, trans. Jane Lewin, Ithaca: Cornell University Press, 1980. [Electronic Resource]. Mode of access:https://archive. org/details/NarrativeDiscourseAnEssaylnMethod/ page/n5/mode/2up

7. Harris, S. (1984). Questions as a mode of control in magistrates'courts'. International Journal of the Sociology of Language 49. P. 5-27.

8. Harris, S. (2005) Telling stories and giving evidence: The hybridisation of narrative and nonnarrative modes of discourse in a sexual assault trial'. In Thorn borrow and Coates (2005). P. 215-237.

9. Heffer, C. (2002) If you were Standing in Marks and Spencers': Narrativisation and Comprehension in the English Summing-Up'. In Cotterill (2002). P. 228-45

10. Heffer, C. (2005) The Language of Jury Trial: A Corpus-Aided Analysis of Legal-Lay Discourse. Basingstoke: Palgrave. 253 p.
11.Luchjenbroers, J. (1997) "In Your Own Words ": Questions and Answers win a Supreme Court Trial', Journal of Pragmatics, vol. 27, P. $477-503$

12. Maley, Yon; Fahey, Rhondda. (1991) Presenting the evidence: Constructions of reality in court. Department of Linguistics. International Journal for the Semiotics of Law 4. (10), P. 3-17.

13. Norrick, Neal R. (2005) Conversational Storytelling. D. Herman (ed). The Cambridge Companion to Narrative. Cambridge: Cambridge UP, P. 127-141.

14. Smith M. J. Police interviews [Electronic Resource]. - Mode of access: http://Cryptome.org/smith-inter.zip

15. The Lisa McPherson Files, Interviews [Electronic Resource]. - Mode of access: http://www.lisafiles.com/police/interviews/219.htm, The Lisa McPherson Files, Interviews.

\title{
НАРАТИВ У ДИСКУРСІ ДОПИТУ Л. В. Павліченко
}

\begin{abstract}
Анотація. Актуальність дослідження пояснюється відповідністю сучасним науковим розвідкам у галузі когнітивно-дискурсивної парадигми щодо прагматичних фракторів оптимізації усної інституційної комунікації, вивчення мовленнєвого впливу, запобігання та подолання невдач та конфрліктної комунікації. Метою дослідження $є$ аналіз комунікативно-прагматичних характеристик наративу допитуваного в дискурсі допиту на етапі досудового слідства. Висновки. Формальність, трафраретність та ритуалізація дискурсу допиту характеризується наявністю структурноінваріантних частин у діалогічному тексті допиту: «вступ», «спрямована розповідь» та «перевірка». Специсріка хронотопу полягає в тому, що прототипним місцем спілкування є кабінет слідчого; дискурс допиту відзначається анахронізмом (невідповідністю часу дискурсу та часу розповіді), що виявляється у використанні різних граматичних фоорм дієслова та прислівників для часу дискурсу $i$ часу "оповідань". Характерною рисою інституційної фоорми допиту $є$ поєднання наративу 3 діалогічним спілкуванням, в процесі якого слідчий уточнює, перефрормульовує або розширює наратив допитуваного за допомогою навідних питань та коментарів. Слідчий керує наративом оповідача, зосереджуючи увагу на деталях історії з метою відновлення забутих або ненавмисно пропущених фактів; застосовуючи маніпулятивні прийоми i тактики, попереджаючи про кримінальну відповідальність, використовуючи викладену історію як основу для інтерпретації інших фрактів справи.
\end{abstract}

Ключові слова: слідчий, допитувана особа, дискурс допиту, досудове розслідування, скерований наратив, діалогічне спілкування. 